International Research Journal of Management, IT \& Social Sciences (IRJMIS) Journal Homepage: http://ijcu.us/online/journal/index.php/irjmis Vol. 3Issue 7, July 2016, pp. 11 22

ISSN: 2395-7492 Impact Factor: 3.552

DOI:10.6084/m9.figshare.3439814 | ORCID: 0000-0002-8751-0913 | Thomson Reuters |C-6767-2016 |

\title{
Salaried Strata Investment Behavior towards Financial Products-Review and Prospects for Future Research
}

\author{
Monika Dahiya * \\ Bhuvnender Chaudhary ${ }^{* *}$
}

Article history:

Received April 5 $5^{\text {th }}, 2016$

Revised May $10^{\text {th }}, 2016$

Approved June $18^{\text {th }}, 2016$

\section{Keywords:}

Investment Behavior;

Salaried people;

Financial Products;

Factors- Demographic;

Socio Economic.

\begin{abstract}
The financial surface of the globe at all times reveals a weird balanced impact of the public investment preferences, their understanding about the investment requirements, their anticipation of returns on their investments etc. Perhaps forecasting the growth of the business world would be crucial without an apposite comprehension of the investment behavior of the key part of the society called salaried class. This paper covers appraisal of various financial instruments like equity/stocks, term deposits in banks, kisan vikas patra, national savings certificate, insurance policies, mutual fund and converse the factors persuading investment decision process. The major factors influencing the financial investment behavior are demographic factors (like age, income, qualification, gender, etc.) and socio-economic factors (like family income, tax benefits, safety of fund, risk inclination, return on investment). This study aims to serve a channel to the need of a comprehension of the financial objectives of the salaried class investors with that of their determined desire for the investment returns. Certainly, this information could unwrap the prospect of predicting even the future of Indian Economy itself besides, providing span to fine-tuning the investment prudence of the public towards progressive and fruitful choices for themselves and the nation.
\end{abstract}

Copyright@ 2016 International Journal of College and University. All rights reserved.

Article cited by | DOI |Orcid | OAI DOAJ | Thomson Reuters | Scopus |

\section{Author correspondence:}

First Author,

Research Scholar, Management Department

Uttarakhand Technical University,

Dehradun, Uttarakhand, India

Email: moni.dahiya89@gmail.com

\section{Introduction}

The financial system of India comprises financial institutions, financial markets, financial instruments and services. Efficient transfer of resources from those having idle resources to others who have a pressing need for them is achieved through financial markets. Stated formally, financial markets provide channels for allocation of savings to investment. These provide a variety of assets to savers as well as various forms in which the investors can raise funds and thereby decouple the acts of saving and investment. The savers and investors are constrained not by their individual abilities, but by the economy's ability, to invest and save respectively. The financial markets, thus, contribute to economic development to the extent that the latter depends on the rates of savings and investment. Financial markets are full of imperfections, which make results inconsistent with the expectations. Genuine conditions apart, in the present world of finance, human greed, system failures or national afflictions can make things very unpredictable. This is where risk comes

${ }^{*}$ Research Scholar, Management Department, Uttarakhand Technical University,Dehradun, Uttarakhand, India

${ }^{* *}$ Professor, Management Department, Phonics Group of Institutions, Roorkee, Uttarakhand, India 
into play and enroots to investor behavior in different manners. The behavior of the Investor can be affected by a number of factors. Demographical factors play vital role in determining individual buying behavior for any goods or even service. Many researches have been conducted to identify Investor buying behavior to identify how Investors specifically salaried strata are making financial planning to satisfy their future financial need as they have a fixed income flow. In financial sector since reforms, many new private (domestic and foreign) players have had come up to influence the buying behavioral pattern of Indian Investors specifically for financial assets. Many of us have one simple approach to dealing with risk. That is to avoid it by all means. In financial investment matters, this may not be a good strategy. As risk and return are correlated, every risk you are avoiding possibly deprives you of a handsome opportunity to build your wealth. Balancing risk with return in line with your individual circumstances is what financial market management is all about.

The aim of this study is to appraise various financial instruments like equity/stocks, term deposits in banks, kisan vikas patra, national savings certificate, insurance policies, mutual fund and converse the factors persuading investment decision process and to analyze the impact of major factors influencing the financial investment behavior are demographic factors (like age, income, qualification, gender, etc.) and socioeconomic factors (like family income, tax benefits, safety of fund, risk inclination, return on investment) by exploring and comprehending the diverse literature available worldwide for understanding the variables that governs an investor's decision to save and invest.

Over the last two decades, investor deportment has been put under the microscope for analyzing their decision making process and the factors that impact their investment behavior. The assessment of behavioral finance leads researchers to examine the psychological traits of investors and how they induce their investment decision making strategies in various investment instruments.

\section{Research Method}

In the present study, a thorough review of the existing pragmatic literature from the has been conducted. Articles published in various online databases and search engines such as NBER, INDIASTAT, ProQuest, JSTOR, OECD library and Google scholar along with relevant books on the topic were reviewed. The studies have been reviewed in terms of crucial measures like objectives, research methodology, sample and the factors that influence an investor's behaviour. Studies were conducted to identify the research gap and to propose an empirical study to determine the relationship between the income, saving and investment behavior among the salaried class people.

\section{Results and Analysis}

Table 1 - Existing Empirical Literature Focusing on Saving and Investment Behaviour

\begin{tabular}{|c|c|c|c|c|}
\hline $\begin{array}{l}\text { Author (Year } \\
\text { of study) }\end{array}$ & Objective of research & Sample & $\begin{array}{l}\text { Research } \\
\text { Methodology }\end{array}$ & Findings of the study \\
\hline Lal (1992) & $\begin{array}{l}{[1] \text { To know the profile }} \\
\text { of } \\
\text { Indian investors }\end{array}$ & 1200 & $\begin{array}{l}\text { Descriptive } \\
\text { Analysis }\end{array}$ & $\begin{array}{l}\text { The Indian investors } \\
\text { preferred to } \\
\text { invest in larger portfolios } \\
\text { with } \\
\text { more than five } \\
\text { companies. }\end{array}$ \\
\hline $\begin{array}{l}\text { Gupta } \\
\text { (1993) }\end{array}$ & $\begin{array}{l}\text { To analyse the } \\
\text { changing } \\
\text { patterns of ownership } \\
\text { of } \\
\text { Indian Households }\end{array}$ & $\begin{array}{l}40998 \text { unit } \\
\text { holders and } \\
165819 \\
\text { shareholders } \\
\text { from over } 19 \\
\text { states/union } \\
\text { territories and } \\
76 \text { cities in } \\
\text { India } \\
\end{array}$ & $\begin{array}{l}\text { Descriptive } \\
\text { Analysis }\end{array}$ & $\begin{array}{l}\text { The study revealed a } \\
\text { massive shift towards } \\
\text { units/mutual } \\
\text { products, a moderate } \\
\text { continuing shift towards } \\
\text { shares and debentures } \\
\text { and a shift away from } \\
\text { traditional financial } \\
\text { assets. }\end{array}$ \\
\hline $\begin{array}{l}\text { Nage And } \\
\text { Obenber } \\
\text { ger }(1994)\end{array}$ & $\begin{array}{l}\text { To study the factors } \\
\text { influencing the } \\
\text { individual } \\
\text { investor behaviour }\end{array}$ & 300 & Factor Analysis & $\begin{array}{l}\text { They developed a } \\
\text { questionnaire that } \\
\text { included } 34 \text { factors such } \\
\text { as expected corporate } \\
\text { earnings, diversification } \\
\text { needs, feelings past } \\
\text { performance of stocks, }\end{array}$ \\
\hline
\end{tabular}




\begin{tabular}{|c|c|c|c|c|}
\hline & & & & $\begin{array}{l}\text { past } \\
\text { performance of their own } \\
\text { portfolio, stock broker } \\
\text { recommendations to } \\
\text { name a few. }\end{array}$ \\
\hline $\begin{array}{l}\text { Embrey and } \\
\text { Fox (1997) }\end{array}$ & $\begin{array}{l}\text { To explore gender } \\
\text { differences in the } \\
\text { investment decision } \\
\text { making process. }\end{array}$ & $\begin{array}{l}839 \\
\text { single-person } \\
\text { households. }\end{array}$ & $\begin{array}{l}\text { Descriptive } \\
\text { Analysis }\end{array}$ & $\begin{array}{l}\text { Women were more likely } \\
\text { to hold } \\
\text { risky assets if expecting } \\
\text { an inheritance, employed } \\
\text { and } \\
\text { holding higher net worth; } \\
\text { while } \\
\text { men invested in risky } \\
\text { assets if they were risk } \\
\text { seekers, divorced, older, } \\
\text { and college educated. }\end{array}$ \\
\hline $\begin{array}{l}\text { NCAER } \\
(2000)\end{array}$ & $\begin{array}{l}\text { [2]To study the primary } \\
\text { considerations of the } \\
\text { investors while } \\
\text { choosing a } \\
\text { financial instruments }\end{array}$ & 288081 & $\begin{array}{l}\text { Descriptive } \\
\text { Analysis }\end{array}$ & $\begin{array}{l}\text { Safety and liquidity were } \\
\text { the primary } \\
\text { considerations of the } \\
\text { investors while choosing } \\
\text { an asset. }\end{array}$ \\
\hline $\begin{array}{l}\text { Athukorala } \\
\text { And Sen } \\
\text { (2001) }\end{array}$ & $\begin{array}{l}\text { To examine the } \\
\text { determinants of the } \\
\text { private } \\
\text { saving rate in India } \\
\text { during } \\
\text { the period } 1954 \text { to } 1998\end{array}$ & India & $\begin{array}{l}\text { Case Study, } \\
\text { Time Series } \\
\text { Analysis }\end{array}$ & $\begin{array}{l}\text { The saving rate rises with } \\
\text { both the level and the rate } \\
\text { of growth of disposable } \\
\text { income and the } \\
\text { magnitude of the impact } \\
\text { of the former is smaller } \\
\text { than that of the latter. }\end{array}$ \\
\hline Rajarajan(2003) & $\begin{array}{l}\text { [3]To study the } \\
\text { determinants } \\
\text { of portfolio choice of } \\
\text { individual investors }\end{array}$ & $\begin{array}{l}405 \\
\text { individuals } \\
\text { from Chennai }\end{array}$ & $\begin{array}{l}\text { Multiple } \\
\text { Regression } \\
\text { Analysis }\end{array}$ & $\begin{array}{l}\text { The expected rate of } \\
\text { return on investments, } \\
\text { risk bearing capacity of } \\
\text { investors and investors } \\
\text { loss avoidance } \\
\text { behaviour had a positive } \\
\text { relationship while the } \\
\text { locus of control had a n } \\
\text { inverse } \\
\text { relationship between the } \\
\text { portfolio choice. }\end{array}$ \\
\hline $\begin{array}{l}\text { Kiran and } \\
\text { Rao (2004) }\end{array}$ & $\begin{array}{l}\text { To identify the investor } \\
\text { group segments on the } \\
\text { basis of demographic } \\
\text { and } \\
\text { psychographic } \\
\text { characteristics of } \\
\text { investors }\end{array}$ & $\begin{array}{l}96 \\
\text { respondents }\end{array}$ & $\begin{array}{l}\text { Multinominal } \\
\text { Logistic } \\
\text { Regression and } \\
\text { Factor Analysis }\end{array}$ & $\begin{array}{l}\text { Four major investor } \\
\text { segments were identified } \\
\text { based on } \\
\text { demographic } \\
\text { psychographic } \\
\text { characteristics. The risk } \\
\text { bearing } \\
\text { capacity of an individual } \\
\text { was } \\
\text { strongly dependent on the } \\
\text { demographic and } \\
\text { psychographic a } \\
\text { characteristics }\end{array}$ \\
\hline $\begin{array}{l}\text { Wood and } \\
\text { Zaichkowsk }\end{array}$ & $\begin{array}{l}\text { [4]To identify and } \\
\text { characterise individual }\end{array}$ & 90 & $\begin{array}{l}\text { Hierarchical } \\
\text { cluster analysis }\end{array}$ & $\begin{array}{lrr}\text { Four } & \text { segments } & \text { of } \\
\text { investors } & \text { namely } & \text { risk }\end{array}$ \\
\hline
\end{tabular}




\begin{tabular}{|c|c|c|c|c|}
\hline y (2004) & $\begin{array}{l}\text { investors into segments } \\
\text { based on their investing } \\
\text { attitudes and behaviour. }\end{array}$ & & $\begin{array}{l}\text { linkage and } \\
\text { ANOVA }\end{array}$ & $\begin{array}{l}\text { tolerant traders, confident } \\
\text { traders , loss averse } \\
\text { traders and conservative } \\
\text { long } \\
\text { term traders were } \\
\text { identified. }\end{array}$ \\
\hline $\begin{array}{l}\text { SCMRD } \\
\text { (2005) }\end{array}$ & $\begin{array}{l}\text { [5]To understand the } \\
\text { problems and need of } \\
\text { the } \\
\text { investor }\end{array}$ & $\begin{array}{l}5908 \\
\text { household } \\
\text { investors }\end{array}$ & $\begin{array}{l}\text { Descriptive } \\
\text { Analysis }\end{array}$ & $\begin{array}{l}\text { Too much volatility and } \\
\text { price manipulation were } \\
\text { found to be the major } \\
\text { cause of worries of the } \\
\text { retail investors. }\end{array}$ \\
\hline $\begin{array}{l}\text { Gupta and } \\
\text { Jain (2008) }\end{array}$ & $\begin{array}{l}\text { To bring out the } \\
\text { investors } \\
\text { preferences among the } \\
\text { various types of } \\
\text { financial } \\
\text { assets and also their } \\
\text { problems concerning } \\
\text { the } \\
\text { stock market. }\end{array}$ & $\begin{array}{l}1463 \\
\text { households }\end{array}$ & $\begin{array}{l}\text { Descriptive } \\
\text { Analysis }\end{array}$ & $\begin{array}{l}\text { The household investors } \\
\text { preferred investing in } \\
\text { shares as } \\
\text { compared to mutual } \\
\text { funds due to relatively } \\
\text { lower returns because } \\
\text { of entry loads and } \\
\text { management fees charged } \\
\text { by the funds. }\end{array}$ \\
\hline $\begin{array}{l}\text { Kibet et al } \\
(2009)\end{array}$ & $\begin{array}{l}\text { To investigate the } \\
\text { factors } \\
\text { that influence savings } \\
\text { among households of } \\
\text { teachers, entrepreneurs } \\
\text { andfarmers in rural } \\
\text { parts of Nakuru } \\
\text { District. }\end{array}$ & 359 & Regression & $\begin{array}{l}\text { Household income, } \\
\text { nature of businessmen } \\
\text { occupation, gender, } \\
\text { And education level of } \\
\text { household head } \\
\text { positively influenced the } \\
\text { saving behaviour of the } \\
\text { rural households in } \\
\text { Nakuru district, while } \\
\text { credit access, age, and } \\
\text { Dependency ratio } \\
\text { negatively influence } \\
\text { household saving. }\end{array}$ \\
\hline $\begin{array}{l}\text { Kabra, } \\
\text { Mishra and } \\
\text { Dash (2010) }\end{array}$ & $\begin{array}{l}\text { [6] Difference in } \\
\text { perception of } \\
\text { Investor in the decision } \\
\text { of } \\
\text { investing on the basis } \\
\text { of } \\
\text { Age. Difference in } \\
\text { perception of Investor } \\
\text { in } \\
\text { the decision of } \\
\text { investing } \\
\text { on the basis of Gender. }\end{array}$ & 150 & $\begin{array}{l}\text { Factor and } \\
\text { Regression } \\
\text { analysis }\end{array}$ & $\begin{array}{lr}\text { Security, } & \text { Opinion, } \\
\text { Awareness, } & \text { Hedging, } \\
\text { Duration and } & \text { Benefits } \\
\text { affect } & \text { individual } \\
\text { investment } & \\
\text { decisions. } & \end{array}$ \\
\hline $\begin{array}{l}\text { Alleyeneand } \\
\text { Broome } \\
(2010)\end{array}$ & $\begin{array}{l}{[7] \text { To determine }} \\
\text { individual } \\
\text { factors that are likely to } \\
\text { influence the } \\
\text { investment } \\
\text { decisions of potential } \\
\text { investors }\end{array}$ & 104 & $\begin{array}{l}\text { Hierarchical } \\
\text { Regression } \\
\text { Analysis }\end{array}$ & $\begin{array}{l}\text { Attitudes and referent } \\
\text { groups (peers, family and } \\
\text { significant others) and } \\
\text { beliefs about potential } \\
\text { obstacles and } \\
\text { opportunities } \\
\text { significantly predict } \\
\text { intentions to invest. }\end{array}$ \\
\hline $\begin{array}{l}\text { Rehman, } \\
\text { Bashir and } \\
\text { Faridi }\end{array}$ & $\begin{array}{l}\text { [8]To explore the socio } \\
\text { economic and } \\
\text { demographic factors }\end{array}$ & 292 & $\begin{array}{l}\text { Multiple } \\
\text { Regression } \\
\text { Analysis } \\
\end{array}$ & $\begin{array}{l}\text { Savings of low and } \\
\text { middle income group is } \\
\text { positively related to total }\end{array}$ \\
\hline
\end{tabular}




\begin{tabular}{|c|c|c|c|c|}
\hline (2011) & $\begin{array}{l}\text { influencing household } \\
\text { savings of various } \\
\text { income groups }\end{array}$ & & & $\begin{array}{l}\text { dependency rate } \\
\text { and total income. Higher } \\
\text { income } \\
\text { households are likely to } \\
\text { save more due to age, } \\
\text { spouse participation, total } \\
\text { income and } \\
\text { size of land holdings }\end{array}$ \\
\hline $\begin{array}{l}\text { Arti, Julee, } \\
\text { andSunita } \\
(2011)\end{array}$ & $\begin{array}{l}\text { To study the } \\
\text { differences in } \\
\text { the Investment } \\
\text { Decision } \\
\text { Making (IDM) process } \\
\text { between female and } \\
\text { male } \\
\text { investors }\end{array}$ & 200 & Chi-square & $\begin{array}{l}\text { Higher level of } \\
\text { awareness for males than } \\
\text { females for different } \\
\text { investment avenues. } \\
\text { Female } \\
\text { investors tend to display } \\
\text { less confidence in their } \\
\text { investment } \\
\text { decisions and hence have } \\
\text { lower satisfaction levels. }\end{array}$ \\
\hline $\begin{array}{l}\text { NCAER } \\
(2011)\end{array}$ & $\begin{array}{l}\text { To understand the } \\
\text { behaviour of household } \\
\text { investors in dealing } \\
\text { with } \\
\text { various financial } \\
\text { instruments which were } \\
\text { traded in markets } \\
\text { regulated } \\
\text { by SEBI }\end{array}$ & $\begin{array}{l}38000 \\
\text { households } \\
\text { across } 44 \\
\text { cities and } 40 \\
\text { villages }\end{array}$ & $\begin{array}{l}\text { Descriptive } \\
\text { Analysis }\end{array}$ & $\begin{array}{l}\text { The survey revealed } \\
\text { relatively low rates of } \\
\text { participation by the } \\
\text { households in the } \\
\text { securities market. The } \\
\text { degree of risk aversion } \\
\text { was found to be } \\
\text { extremely high in Indian } \\
\text { households and so } \\
\text { commercial banks and } \\
\text { insurance schemes } \\
\text { were their primary choice } \\
\text { for saving and } \\
\text { investment. }\end{array}$ \\
\hline $\begin{array}{l}\text { Delafrooz } \\
\text { andPaim } \\
(2011)\end{array}$ & $\begin{array}{l}\text { To examine } \\
\text { determinants } \\
\text { that influence financial } \\
\text { wellness }\end{array}$ & 2000 & $\begin{array}{l}\text { Descriptive } \\
\text { Analysis }\end{array}$ & $\begin{array}{l}\text { There is relationship of } \\
\text { savings behaviour and } \\
\text { financial problems to } \\
\text { financial literacy, } \\
\text { financial stress and } \\
\text { financial management } \\
\text { practice. }\end{array}$ \\
\hline $\begin{array}{l}\text { Kothari } \\
(2012)\end{array}$ & $\begin{array}{l}\text { [9] To analyse } \\
\text { investors' } \\
\text { behaviour towards } \\
\text { investment avenues in } \\
\text { Indore city. }\end{array}$ & 100 & $\begin{array}{l}\text { Mean and } \\
\text { Standard } \\
\text { Deviation }\end{array}$ & $\begin{array}{l}\text { The investors belonging } \\
\text { to different age groups } \\
\text { have different behaviour } \\
\text { while doing } \\
\text { Investment and their } \\
\text { selection of any } \\
\text { investment avenue highly } \\
\text { depends upon their age. }\end{array}$ \\
\hline $\begin{array}{l}\text { Harikanth } \\
\text { and Pragathi } \\
(2012)\end{array}$ & $\begin{array}{l}\text { [10]To explore the } \\
\text { psychological concept } \\
\text { of } \\
\text { individual attachment } \\
\text { style, especially } \\
\text { individual } \\
\text { investors to different } \\
\text { available investment } \\
\text { avenues and their } \\
\text { investment preference }\end{array}$ & 270 & $\begin{array}{l}\text { Descriptive } \\
\text { Analysis }\end{array}$ & $\begin{array}{l}\text { There is a significant role } \\
\text { of income and occupation } \\
\text { in investment avenue } \\
\text { selection by the male and } \\
\text { female investors. }\end{array}$ \\
\hline
\end{tabular}




\begin{tabular}{|c|c|c|c|c|}
\hline & process. & & & \\
\hline Bahl (2012) & $\begin{array}{l}\text { [11]To study the } \\
\text { investment behavior } \\
\text { among the working } \\
\text { women in Punjab }\end{array}$ & 100 & $\begin{array}{l}\text { Descriptive } \\
\text { analysis }\end{array}$ & $\begin{array}{l}\text { Working women invest } \\
\text { their money in insurance } \\
\text { plans. The } \\
\text { less financially literate } \\
\text { are less likely to engage } \\
\text { in recommended } \\
\text { financial practices, such } \\
\text { as planning for } \\
\text { retirement. }\end{array}$ \\
\hline $\begin{array}{l}\text { Kumar } \\
\text { Vijayabanuand } \\
\text { Amudha } \\
\text { (2012) }\end{array}$ & $\begin{array}{l}\text { To analyse the } \\
\text { influence of the } \\
\text { financial literacy level } \\
\text { on individual } \\
\text { investment decisions. }\end{array}$ & $\begin{array}{l}469 \text { investors } \\
\text { from } \\
\text { Tiruchirapalli }\end{array}$ & $\begin{array}{l}\text { Descriptive } \\
\text { analysis, Chi } \\
\text { Square, }\end{array}$ & $\begin{array}{l}\text { Except the gender, there } \\
\text { exists a } \\
\text { relationship between the } \\
\text { socioeconomic } \\
\text { factors and the level of } \\
\text { financial literacy } \\
\text { possessed by } \\
\text { the respondents. }\end{array}$ \\
\hline $\begin{array}{l}\text { Bhatt and } \\
\text { Bhatt (2012) }\end{array}$ & $\begin{array}{l}\text { [12To study preference } \\
\text { level of individual } \\
\text { towards various } \\
\text { investment avenues, to } \\
\text { find out the frequency } \\
\text { and the factors that } \\
\text { influences on } \\
\text { investments and to } \\
\text { measure risk ability of } \\
\text { different class of } \\
\text { people. }\end{array}$ & 200 & $\begin{array}{l}\text { Descriptive } \\
\text { analysis, Two } \\
\text { way ANOVA }\end{array}$ & $\begin{array}{l}\text { Majority of investors } \\
\text { prefer bank deposit } \\
\text { because of less risk. } \\
\text { Investors who have less } \\
\text { education and income } \\
\text { compare to other, they } \\
\text { also prefer bank } \\
\text { deposit, post office } \\
\text { deposit and insurance } \\
\text { because of easy to } \\
\text { understand and less risk. }\end{array}$ \\
\hline $\begin{array}{l}\text { Samudra and } \\
\text { Burghate } \\
\text { (2012) }\end{array}$ & $\begin{array}{l}\text { To know the preference } \\
\text { of } \\
\text { investment instruments, } \\
\text { to } \\
\text { know the various } \\
\text { objectives } \\
\text { investment } \\
\text { and to know whether } \\
\text { there has been increase } \\
\text { in the savings and the } \\
\text { reasons for the same. }\end{array}$ & $\begin{array}{l}300 \\
\text { households }\end{array}$ & $\begin{array}{l}\text { Descriptive } \\
\text { Analysis }\end{array}$ & $\begin{array}{l}\text { Bank deposits, insurance } \\
\text { and } \\
\text { small saving schemes } \\
\text { such as Public provident } \\
\text { fund, Post } \\
\text { office saving deposits are } \\
\text { preferred investment } \\
\text { options. }\end{array}$ \\
\hline $\begin{array}{l}\text { Jain and } \\
\text { Ranawat } \\
\text { (2012) }\end{array}$ & $\begin{array}{l}\text { [13]To examine the } \\
\text { association of } \\
\text { demographic factors on } \\
\text { investment choices. }\end{array}$ & 100 & Chi Square test & $\begin{array}{l}\text { There is association of } \\
\text { demographic profiles } \\
\text { and personality type of } \\
\text { the investors with } \\
\text { investment choice. } \\
\text { Investors with higher } \\
\text { income group prefer to } \\
\text { invest in real estate and } \\
\text { females prefer to } \\
\text { invest } \\
\text { old/commodities. } \\
\text { Females } \\
\text { conservative while } \\
\text { Investing and males were } \\
\text { aggressive. }\end{array}$ \\
\hline $\begin{array}{l}\text { Jain and Jain } \\
(2012)\end{array}$ & $\begin{array}{l}{[14] \text { To determine the }} \\
\text { relationship between }\end{array}$ & 100 & $\begin{array}{l}\text { Descriptive } \\
\text { Analysis }\end{array}$ & $\begin{array}{l}\text { In spite of low income } \\
\text { the teachers have been }\end{array}$ \\
\hline
\end{tabular}




\begin{tabular}{|c|c|c|c|c|}
\hline & $\begin{array}{l}\text { the } \\
\text { savings and } \\
\text { investments } \\
\text { literacy among the } \\
\text { school } \\
\text { teachers. }\end{array}$ & & & $\begin{array}{l}\text { saving for future needs. } \\
\text { The main avenues } \\
\text { of investment are Bank } \\
\text { deposits and the main } \\
\text { purpose of investment is } \\
\text { for children education, } \\
\text { marriage, and security } \\
\text { after retirement. }\end{array}$ \\
\hline $\begin{array}{l}\text { Murithi, } \\
\text { Narayanan } \\
\text { andArivazha } \\
\text { gan (2012) }\end{array}$ & $\begin{array}{l}{[15] \text { To stud the }} \\
\text { investors } \\
\text { behaviour towards } \\
\text { various } \\
\text { investment avenues }\end{array}$ & 100 & $\begin{array}{l}\text { Descriptive } \\
\text { analysis and } \\
\text { Correlation }\end{array}$ & $\begin{array}{l}\text { The individual investors } \\
\text { still prefer to invest in } \\
\text { financial products which } \\
\text { give risk free } \\
\text { returns }\end{array}$ \\
\hline $\begin{array}{l}\text { Sireesha and } \\
\text { Laxmi } \\
(2013)\end{array}$ & $\begin{array}{l}\text { [16]To find out the } \\
\text { impact of demographic } \\
\text { factors on } \\
\text { investment avenues } \\
\text { selected by investors in } \\
\text { the twin cities of } \\
\text { Hyderabad and } \\
\text { Secunderabad, India }\end{array}$ & 165 & $\begin{array}{l}\text { Descriptive } \\
\text { analysis }\end{array}$ & $\begin{array}{l}\text { It is found that gender, } \\
\text { age and friends are } \\
\text { mostly influencing the } \\
\text { investment decisions of } \\
\text { the respondents. It is } \\
\text { concluded that the } \\
\text { respondents of the study } \\
\text { are conservative in nature } \\
\text { and show less concern for } \\
\text { money multiplication and } \\
\text { liquidity. }\end{array}$ \\
\hline $\begin{array}{l}\text { Bhushanand } \\
\text { Medury } \\
(2013)\end{array}$ & $\begin{array}{l}\text { To analyse the gender } \\
\text { differences in } \\
\text { investment } \\
\text { behaviour among } \\
\text { employees }\end{array}$ & 118 & Chi Square & $\begin{array}{l}\text { There is significant } \\
\text { gender differences that } \\
\text { occur in investment } \\
\text { preferences for health } \\
\text { insurance, fixed deposits } \\
\text { and market investments } \\
\text { among employees. }\end{array}$ \\
\hline $\begin{array}{l}\text { Jayaraj } \\
(2013)\end{array}$ & $\begin{array}{l}\text { [17]To identify the } \\
\text { factors } \\
\text { which determine } \\
\text { individual investor } \\
\text { investment behaviour. } \\
\text { To know whether any } \\
\text { psychological biases } \\
\text { exist } \\
\text { among Indian investors }\end{array}$ & 300 & $\begin{array}{l}\text { Principle } \\
\text { component } \\
\text { analysis }\end{array}$ & $\begin{array}{l}\text { The results reveal that the } \\
\text { psychological axes } \\
\text { conservatism, diligent } \\
\text { and discreet, remorse } \\
\text { abhorrence fall in line } \\
\text { with the earlier research } \\
\text { but prudence and under } \\
\text { confidence are the } \\
\text { contrary behaviour axes } \\
\text { reported by the } \\
\text { multivariate analysis. }\end{array}$ \\
\hline $\begin{array}{l}\text { Bashir, } \\
\text { Ahmed, } \\
\text { Jahangir, } \\
\text { Zaigam, } \\
\text { Saeed } \\
\text { andShafi } \\
(2013)\end{array}$ & $\begin{array}{l}{[18] \text { To analyse the }} \\
\text { relationship } \\
\text { of demographic } \\
\text { variables } \\
\text { with the investment } \\
\text { preferences consisting } \\
\text { of } \\
\text { stock investment and } \\
\text { gambling decisions of } \\
\text { salaried individuals of } \\
\text { finance teachers } \\
\text { and bankers of Gujarat } \\
\text { and } \\
\text { Sialkot }\end{array}$ & 120 & $\begin{array}{l}\text { Descriptive } \\
\text { Analysis, } \\
\text { Correlation }\end{array}$ & $\begin{array}{l}\text { Females are more risk } \\
\text { averse than males. Young } \\
\text { and educated people are } \\
\text { attracted more towards } \\
\text { new risky investment } \\
\text { opportunities and are } \\
\text { reluctant because of } \\
\text { limited resources and } \\
\text { lack of investment } \\
\text { opportunities and absence } \\
\text { of investment trends. The } \\
\text { emergence of frequent } \\
\text { religious issues, non } \\
\text { conducive } \\
\text { economic environment }\end{array}$ \\
\hline
\end{tabular}




\begin{tabular}{|c|c|c|c|c|}
\hline & & & & $\begin{array}{l}\text { and culture has negative } \\
\text { relationship with } \\
\text { gambling while making } \\
\text { investment decisions. }\end{array}$ \\
\hline $\begin{array}{l}\text { Bhardwaj, } \\
\text { Sharma and } \\
\text { Sharma } \\
\text { (2013) }\end{array}$ & $\begin{array}{l}{[19] \text { To throw light on }} \\
\text { the } \\
\text { Investmen tbehavior of } \\
\text { the employees of Bahra } \\
\text { University, Solan } \\
\text { District }\end{array}$ & 50 & $\begin{array}{l}\text { Descriptive } \\
\text { analysis }\end{array}$ & $\begin{array}{l}\text { Most of the employees } \\
\text { are aware of investments } \\
\text { in securities but they are } \\
\text { not investing in it as they } \\
\text { consider it as an unsafe } \\
\text { investment. }\end{array}$ \\
\hline $\begin{array}{l}\text { Palaniveluand } \\
\text { Chandrakum } \\
\text { ar (2013) }\end{array}$ & $\begin{array}{l}\text { To analyze the } \\
\text { investment } \\
\text { choice of salaried class } \\
\text { in } \\
\text { NamakkalTaluk, } \\
\text { TamilNadu, India. }\end{array}$ & 100 & Chi Square & $\begin{array}{l}\text { Certain factors like } \\
\text { Education level, } \\
\text { awareness about the } \\
\text { current financial system, } \\
\text { age of investors makes } \\
\text { significant impact while } \\
\text { deciding the investment } \\
\text { avenues. Awareness } \\
\text { program has to be } \\
\text { conducted by Stock } \\
\text { Broking firms, because } \\
\text { most of the respondents } \\
\text { unaware about new } \\
\text { services. }\end{array}$ \\
\hline $\begin{array}{l}\text { Chhabra and } \\
\text { Mundra } \\
\text { (2014) }\end{array}$ & $\begin{array}{l}\text { [20] To understand and } \\
\text { present a glimpse of } \\
\text { research work done on } \\
\text { the investment } \\
\text { behaviour }\end{array}$ & & $\begin{array}{l}\text { Literature } \\
\text { review }\end{array}$ & $\begin{array}{l}\text { Investment options opted } \\
\text { by people are Currency, } \\
\text { Bank Deposits, Non- } \\
\text { Banking } \\
\text { Deposits, Life Insurance } \\
\text { Fund, Provident Fund\& } \\
\text { Pension Fund, Claims on } \\
\text { Government, Shares \& } \\
\text { Debentures, Units of } \\
\text { UTI, National Saving } \\
\text { Certificates. }\end{array}$ \\
\hline Raza (2014) & $\begin{array}{l}\text { [21]To review the } \\
\text { important } \\
\text { developments in the } \\
\text { field of behavioral } \\
\text { financial and to present } \\
\text { how behavior finance is } \\
\text { the emerging field in } \\
\text { the area of investment } \\
\text { decision making. }\end{array}$ & 50 & $\begin{array}{l}\text { Case Study, } \\
\text { Descriptive } \\
\text { Analysis }\end{array}$ & $\begin{array}{l}\text { The perceptions of the } \\
\text { investors do have a } \\
\text { strong and significant } \\
\text { impact on the financial } \\
\text { decision making of the } \\
\text { investors thus implying } \\
\text { that behavioral finance } \\
\text { in fact duly challenges } \\
\text { the conventional financial } \\
\text { modeling and thus is an } \\
\text { important emerging field } \\
\text { of financial decision } \\
\text { making that definitely } \\
\text { needs to be explored and } \\
\text { studied further }\end{array}$ \\
\hline $\begin{array}{l}\text { Geetha and } \\
\text { Vimala } \\
\text { (2014) }\end{array}$ & $\begin{array}{l}{[22] \text { To identify the }} \\
\text { popular } \\
\text { perception of individual } \\
\text { investors towards } \\
\text { selected } \\
\text { investment avenues and } \\
\text { the predominant factors }\end{array}$ & 500 & $\begin{array}{l}\text { One sample } \\
\text { t-test, Chi- } \\
\text { Square }\end{array}$ & $\begin{array}{l}\text { There is a remarkable } \\
\text { change in the investment } \\
\text { avenues due to } \\
\text { establishment of different } \\
\text { financial institution, } \\
\text { creditable source } \\
\text { attractive return, good }\end{array}$ \\
\hline
\end{tabular}




\begin{tabular}{|c|c|c|c|c|}
\hline & $\begin{array}{l}\text { which influence } \\
\text { individual } \\
\text { to go for savings in that } \\
\text { instrument }\end{array}$ & & & $\begin{array}{l}\text { capital appreciation, and } \\
\text { tax concession. From the } \\
\text { investors point of view } \\
\text { changes in demographic } \\
\text { factor such as age, } \\
\text { income, education, and } \\
\text { occupation have an } \\
\text { influence in the } \\
\text { investment avenue } \\
\text { preference. }\end{array}$ \\
\hline $\begin{array}{l}\text { Bhushan } \\
(2014)\end{array}$ & $\begin{array}{l}\text { [23]To examine the } \\
\text { awareness } \\
\text { level and investment } \\
\text { behaviour of salaried } \\
\text { individuals towards } \\
\text { financial products. }\end{array}$ & 516 & $\begin{array}{l}\text { Descriptive } \\
\text { Statistics }\end{array}$ & $\begin{array}{l}\text { Respondents are quite } \\
\text { aware and park their } \\
\text { money in traditional and } \\
\text { safe financial products } \\
\text { whereas awareness level } \\
\text { of new age financial } \\
\text { products among the } \\
\text { population is low. }\end{array}$ \\
\hline $\begin{array}{l}\text { Monika Dahiya } \\
\text { and Dr. } \\
\text { Bhuvnender } \\
\text { Chaudhary } \\
\text { (2016) }\end{array}$ & $\begin{array}{l}\text { [24]To study the profile } \\
\text { of the salaried } \\
\text { personnel besides, } \\
\text { understanding their } \\
\text { awareness in } \\
\text { association with } \\
\text { efficacy of the } \\
\text { prevalent investment } \\
\text { policies available. }\end{array}$ & 350 & $\begin{array}{l}\text { Percentage } \\
\text { Analysis, Mean } \\
\text { and Standard } \\
\text { Deviation } \\
\text { analysis, Chi- } \\
\text { square test, T- } \\
\text { test }\end{array}$ & $\begin{array}{l}\text { A major percentage of } \\
\text { the salaried investors of } \\
\text { Saharanpur know how to } \\
\text { make good investment } \\
\text { decisions. } \\
\square \text { One third salaried } \\
\text { people of Saharanpur do } \\
\text { not pick e right financial } \\
\text { plan due to lack of } \\
\text { investment awareness. } \\
\square \text { Only } 50 \% \text { of the } \\
\text { salaried people of } \\
\text { Saharanpur has } \\
\text { realization about the } \\
\text { percentage of savings } \\
\text { they have to choose for } \\
\text { future. }\end{array}$ \\
\hline
\end{tabular}

The above studies have investigated various demographic factors such as age, gender, income; education and experience influence the individual investor behaviour. Some studies discovered that traditional and safe instruments are most popular among investors. Gupta and Jain (2008) denoted that the household investors preferred investing in shares as compared to mutual funds due to relatively lower returns because of entry loads and management fees charged by the funds. Alleyene\& Broome (2010) suggested that attitudes and referent groups (peers, family and significant others) and beliefs about potential obstacles and opportunities significantly predict intentions to invest. Researchers identified that the investor's portfolio, preferences, risk perceptions, objective, pattern of investment, their awareness level, factors affecting their investment behaviour and the constraints faced by them are needed to be examined in order to understand their saving and investment behaviour. Various study identified variables such as demographic factors, market factors, risk bearing capacity, lifestyle characteristics, behavioural factors and other factors are personal and financial needs, accounting information, neutral information, firm image and advocate recommendations that govern investor's decision to save and invest.

\subsection{Research Gap}

While investment behaviour has been studied intensively in a general sense towards salaried strata of the economy, minimum research exists with respect to defence personnels (including Airforce, Army and Navy), and Pune, Hyderabad and Bangalore (Known as IT hub) based IT Professionals mind-set towards investment as a subject. IT professionals are considered to be highly remunerated specially if we talk about private sector salaried people and it is becoming talk of the world particularly among youngsters to opt for IT profession because it gives them mental satisfaction and able to improve their quality of life. Also, since Income and Salaried Strata Investment Behavior towards Financial Products-Review and Prospects for Future Research 
Savings are foundation to Investment, it is essential to examine income, savings and investment behavior simultaneously. From this analysis, it follows that the "Domain of Income, Savings and Investment behaviour of defence personnels (including Airforce, Army and Navy) and Pune, Hyderabad and Bangalore based IT professionals" belongs to the under researched area, and as such, it calls for a ample, reliable and well integrated empirical examination of the behaviour of IT professionals towards their savings and investment activities.

\subsection{Scope for Future Research}

Researchers should focus on impact of macro environmental factors on investment strategy. Also, they can focus the variables like gender, comparison of working and non-working females and geographical sites. Future research should also study possible association effects of gender and marital status on different aspects of financial behavior. It has been found that many of the studies were performed in few Asian countries and in India; they have covered Andhra Pradesh, Tamil Nadu, Punjab and Assam. So, researcher can investigate the same for new geographical destination covering urban as well rural areas. Visa Global Financial Literacy Barometer survey's 2012th edition of has ranked India at 23rd in a list of 28 countries on the financial literacy facade, just ahead of Morocco, South Africa and Vietnam. The survey which had total 923 respondents between the age of 18 and 64 also found that Indians are under-invested when it comes to saving for emergencies. Globally, 25 percent of respondents who report they don't have enough funds to cover a personal economic emergency fall into high income categories. The saving rate of any country is a key indicator of economic development since the domestic saving rate is directly related with the investment rate and the lending capacity of the banking system. People are earning more, but they do not know where, when and how to invest it.

\section{Conclusion}

Today the financial services sector has become highly diversified tendering the investor with a wide range of investment avenues. With proper investment strategies and financial planning, investor can increase personal wealth which will contribute to higher economic growth. The individual's decision to invest is greatly influenced by the various benefits each individual wants from owning a particular investment. This paper has examined the published work relating individual investor behaviour. Understanding the saving and investment behaviour could be of great relevance to the investors for their wealth management and to the policy makers, the investment agencies, the researchers as well as managers of the firms to prepare themselves to respond to the varying behaviour of the investor.

\section{Acknowledgement}

This is to show gratitude of the researchers to acknowledge all the contributors to the field of knowledge in the form of subject matter of salaried people investment behaviour towards financial products, which have been used in conducting the present study.Also a great thanks to my co-author for his commitment to this work.

\section{References}

[1] Lal, J. (1992). Understanding Indian Investors. New Delhi: Global Business Press Le Lewellen, Lease and Schlabaum (1997).Patterns of investments strategy and behavior among individual investors. The Journal of Business, 50(3), 296-333.

[2] NCAER (2000).Survey of Indian Investor Households. Conducted by National Council of Applied Economics Research NCAER (2011).How households save and invest Evidence from NCAER Household Survey.

[3] Rajarajan, V. (2003). Determinants of Portfolio choice of individual investors. The Indian Economic Journal, 50(1).

[4] Wood, R. and Zaichkowsky, Lynne Z. (2004). Attitudes and trading behaviour of stock market investors: A segmentation approach. Journal of Behavioural finance. 5(3), 170-179.

[5] SCMRD (2005).Indian Household Investors Survey: The changing market environment.

[6] Kabra, Mishra and Dash (2010). Factors Influencing Investment Decision of Generations in India: An Econometric Study. Asian Journal of Management Research.1 (1), 308-328.

[7] Alleyene\& Broome (2010).An exploratory study of factors influencing investment decisions of potential investors.Central Bank of Barbados.Working Paper.

[8] Arti, Gaur. Julee and Sunita, Sukijha. (2011). Difference in Gender Attitude in Investment Decision Making in India.Research Journal of Finance and Accounting, 2(12), 1-6. 
[9] Kothari, Heena. (2012). Investors Behaviour towards Investment Avenues: A Study with reference to Indore City. Altius Shodh Journal of Management \& Commerce.

[10] Harikanth, D. and Pragathi, B. (2012). Role of Behavioural Finance in Investment Decision Making - A Study on Select Districts of Andhra Pradesh, India. International Journal in Multidisciplinary and Academic Research, 1(4), 1-15.

[11] Bahl, Sarita. (2012). Investment Behaviour of Working Women of Punjab. Arth Prabhand: A Journal of Economics and Management, 1(6), 21-35.

[12] Bhatt, Kaushal. A. and Bhatt, Kinjal. (2012). Effects of Investor Occupation and Education on Choice of Investment: An Empirical Study in India. International Journal of Management, 29(2), 439-453.

[13] Jain, Dhiraj and Khushboo Ranawat. (2012). The Effect of Demographics on Investment Choice: An Empirical Study of Investors in Rajasthan. Journal of Management and Science, 2(2), 42-61.

[14] Jain, Dhiraj and Jain, Parul (2012).Savings and Investment Pattern of School Teachers - A Study With Reference To Udaipur District, Rajasthan. International Journal of Research in Commerce, Economics \& Management, 2(6), 119-127.

[15] Murithi, Suriya.S. , Narayanan, B. and Arivazhagan, M. (2012).Investors Behaviour in Various Investment Avenues - A Study. International Journal of Marketing and Technology, 2(7), 164-189.

[16] Sireesha, P. Bhanu and Laxmi, Shree (2013). Impact of Demographics on Select Investment Avenues: A Case Study of Twin Cities of Hyderabad and Secunderabad, India. International Journal of Marketing, Financial Services \& Management Research, 2(6), 47-55.

[17] Jayaraj, S. (2013). The Factor Model for Determining the Individual Investment behaviour in India, IOSR Journal of Economics and Finance, 1(4), 21-32.

[18] Bashir, T., Ahmed, H. R., Jahangir, S., Zaigam, S., Saeed, H., \&Shafi, S. (2013). Invest ment preferences and risk level: Behaviour of salaried individuals. IOSR Journal of Business and Management, 10(1), 68-78.

[19] Bhardwaj, Bhawana, Sharma, Nisha and Sharma, Dipanker. (2013). Income, Saving and Investment Pattern of Employees of Bahra University, Solan. IJMS, 3(1), 137- 141.

[20] Chhabra, Gaurav and Mundra, Ankesh (201f4). Understanding the Investment Behavior - A Review of Literature. Shiv Shakti International Journal in Multidisciplinary and Academic Research, 3(2), 1-8.

[21] Raza, Anjum (2014). Review of behavioral finance as an emerging field of investment decision making. IOSR Journal of Business and Management, 16(6), 156-172.

[22] Geetha, S.N and Vimala, K. (2014). Perception of Household Individual Investors towards Selected Financial Investment Avenues (With Reference to Investors in Chennai city).Procedia Economics and Finance, 11,360 - 374.

[23] Bhushan, Puneet. (2014). Insights into awareness level and Investment Behaviour of salaried individuals towards Financial Products. International Journal of Engineering, Business and Enterprise Applications, 8(1), 53-57.

[24] Dahiya, Monika and Chaudhary Bhuvnender Dr. (2016). A Study on Salaried Personnel Awareness, Attitude, Expectation and Satisfaction Over Their Investments With Reference To Saharanpur District. Research Journal of Commerce and Behavioural Science 5(6). 


\section{Biography of Authors}

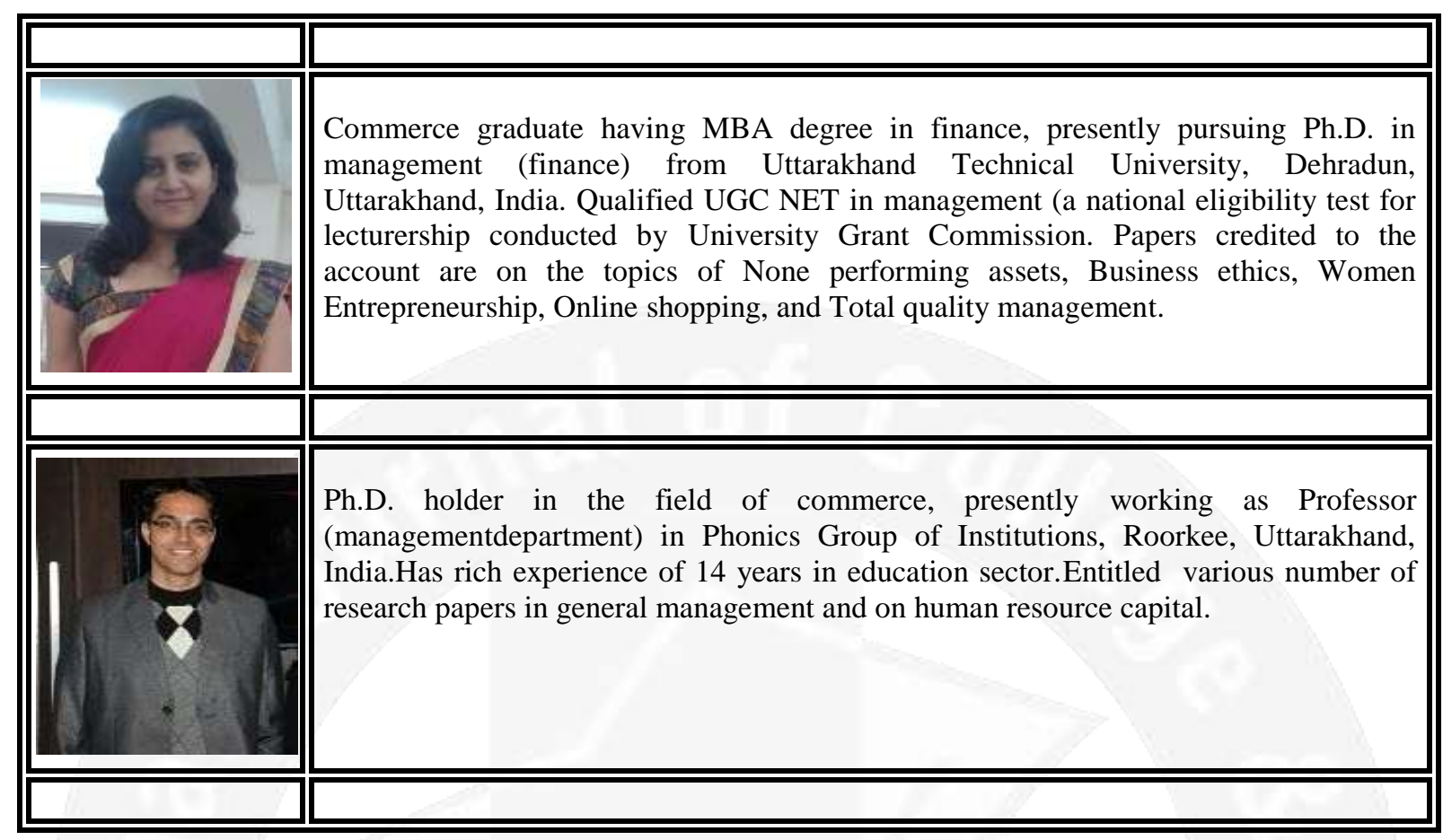

